\title{
A Risk ALLOCATION APPROACH TO OPTIMAL EXCHANGE RATE POLICY
}

\author{
B. GABRIELA MUNDACA \\ JON STRAND
}

CESIFO WORKING PAPER NO. 1361

CATEgory 5: Fiscal Policy, Macroeconomics AND Growth

DECEMBER 2004

\footnotetext{
An electronic version of the paper may be downloaded

- from the SSRN website:

www.SSRN.com

- from the CESifo website:

www.CESifo.de
} 


\title{
A RiSK AlLOCATION APPROACH TO OPTIMAL EXCHANGE RATE POLICY
}

\begin{abstract}
We derive the optimal exchange rate policy for a small open economy subject to terms-oftrade shocks. Firm owners and workers are risk averse but workers more so. Wages are given or partially indexed in the short run, and capital markets are imperfect. The government sets the exchange rate to allocate risk between workers and owners. With less risk-averse firms, and greater difference in risk aversion between workers and firms, the optimal exchange rate should vary little with pure terms-of-trade shocks but more with general shocks to prices. Optimal exchange rate variation is greater with indexed wages, but is smaller when firms behave monopolistically and when wage taxes (profit taxes) change procyclically (countercyclically) with export prices (import prices). The model gives policy rules for determining optimal variations of the exchange rate, and indicates when it is, and is not, optimal to join a currency union with trading partners, implying zero exchange rate variation.
\end{abstract}

JEL Code: F31, F33, F41.

Keywords: currency band, monetary union, price volatility, optimal risk allocation.

\author{
B. Gabriela Mundaca \\ Department of Economics \\ University of Oslo \\ Box 1095, Blindern \\ 0317 Oslo \\ Norway \\ gabriela.mundaca@econ.uio.no
}

\author{
Jon Strand \\ Department of Economics \\ University of Oslo \\ Box 1095, Blindern \\ 0317 Oslo \\ Norway \\ jon.strand@econ.uio.no
}

We thank Eirik Kristiansen, Bennett McCallum, Hans-Werner Sinn, Bent Vale, Erling Vårdal, participants at the CEPR conference on "Euro and Dollarisation: Forms of Monetary Unions and Integrating Regions" (April 2002), and especially to James Forder and two anonymous referees for their valuable comments. The paper is forthcoming in Oxford Economic Papers. 


\section{Introduction}

The choice between fixed and flexible exchange rates, and the "optimal" degree of exchange rate flexibility, has long been fundamental issues in international economics, at least since the seminal contributions of Mundell $(1960,1961)$ and McKinnon (1963). After the breakdown of the Bretton Woods fixed-rate system in the early 1970s the developed world has adopted a number of approaches to the managing of exchange rates. Many of these have involved predetermined currency bands within which each country's exchange rate was allowed to fluctuate relative to particular target currencies, or similar "implicit" (and in practice often narrower) bands. More recently we have witnessed two separate new developments. The first of these is the European currency union whereby most European Union member states have adopted the Euro as a common currency, from the start of 1999. The main purpose of the union can perhaps be viewed as the promotion of economic integration among the member nations, thereby reducing transaction costs and promoting specialization and competition within the union. The exchange rate policy of the Euro area versus the outside world is however less well defined and can most reasonably be described as flexible and demand-oriented. More recently other groups of countries, in Latin America, Africa and the Middle East, are in the process of adopting common currencies. ${ }^{1}$ The second development is the adoption of inflation targets as monetary policy in several OECD countries outside of the Euro area, such as Canada, Great Britain, Denmark, Sweden, Norway, New Zealand and Australia. In these countries the main role of exchange rate policy is the managing of long-run inflation, to be kept in a typical range around $2 \%$.

The purpose of this paper is to study a single government's choice of exchange rate policy focusing on roles of the exchange rate quite different from those just described and from the theoretical approaches in the related literature. We consider a stylized small open economy

\footnotetext{
${ }^{1}$ See Alesina, Barro and Tenreyro (2002) for overviews and discussions of recent development in this area.
} 
where the entire output is exported, all consumption goods are imported, nominal prices abroad are taken as exogenous by all domestic agents, and where competition creates complete passthrough of foreign to domestic prices. We assume that the nominal wage has a high degree of rigidity (in section 2) or is partly indexed to the consumer price level (in section 3 ) for the period in question, while domestic prices are always fully flexible. The government is assumed to announce, and commit to, its exchange rate policy (the nominal exchange rate in each of the possible states that may occur in the "next period"), prior to the revelation of the next-period state. At the time the government announces the exchange rate policy, the "next-period" wage is determined in the private sector. Export and import prices are subject to stochastic i.i.d. shocks, firms are assumed to determine employment unilaterally in each state, and there is always some unemployment in the economy, resulting from short-run wage rigidities, in line with standard approaches in "new Keynesian" macroeconomics.

We assume that individuals in the economy can be separated into one of two distinct groups. The first, workers, consume out of wages, while the second, firm owners, consume out of profits. Within each group, all individuals are assumed to have constant and identical degrees of relative risk aversion, but risk aversion may differ between workers and owners. In our model, the "public" thus cannot be identified by a "representative individual", household, or producer as assumed e.g. by Obstfeld and Rogoff $(1996,1998)$. The risk preferences of individuals in each group are then shown to matter for the government's constrained efficient exchange rate policy, as the exchange rate rule has important consequences for the short-run variations in wages and owner incomes. We will generally assume that workers are more risk averse than firm owners are, following e.g. the traditional implicit labor contracts literature (Azariadis and Stiglitz(1983); Parsons (1986)), e.g. because they have greater immediate consumption needs relative to income, 
and relatively fewer effective means of diversifying risks than firms. This should be true even in the presence of capital markets.

Our main result is that when risk markets are incomplete, the final optimal exchange rate policy serves as a device for sharing macroeconomic risk between the two groups considered. This result is similar to the ones of the "implicit contract" theory where wages are determined out of the direct control of authorities. We find a simple closed-form analytical solution to this problem, one that generalizes the familiar Arrow-Borch condition for optimal risk allocation between two parties (see Borch (1962)). In some important special cases, in particular when only workers are risk averse and only export prices are variable, the optimal rule is to keep the exchange rate invariable over time. That means that the government should commit to a monetary union with relevant trade partners. This main result holds both in the basic case, studied in section 2, and under three extensions of the basic model, in section 3 , to indexation, taxation and imperfect competition. The details of the optimal policy rule are somewhat reacher with each of these extensions, as explained there as well as in the concluding section 4.

In the literature several attempts have been made to derive "optimal" exchange rate rules. Most of this work compares the efficiency of keeping the exchange rate fixed versus letting it be (fully or partly) flexible. Hamada and Sakurai (1978), Flood (1979), Flood and Marion (1982), Aizenman and Frenkel (1985), Glick and Wihlborg (1990), Hodrick (1989), Weber (1981), Artis and Currie (1981) and Fukuda and Hamada (1987), all extend Mundell's framework to include roles for expectations. Artis and Currie (1981) and Fukuda and Hamada (1987) find that both output and prices are stabilized under fixed rates with "velocity shocks", and destabilized with "demand shocks", and that the choice between regimes rests on which of these types of shocks is more important. Most of these papers are based on ad-hoc criteria, usually involving outputinflation tradeoffs, and not on optimization from "first principles". A different strand of the 
literature, represented by Lucas (1982), Helpman and Razin (1982), Magill and Quinzi (1996) and Neumeyer (1998), focuses on the roles for exchange rates in allocating risk in general equilibrium models with incomplete markets. In particular, Neumeyer finds that a monetary union is under certain assumptions preferable to a system of flexible exchange rates, provided that the gains thereby achieved, due to elimination of excess volatility of nominal variables, exceed the cost of changing the asset structure. A large recent literature (e.g. Frankel and Rose (1997, 1998), Devereux and Engel (2000), and Corsetti and Pesenti (2001, 2002)) studies the optimum currency area issue from welfare-maximizing standpoints. The comparison is however also here between a currency union and a flexible exchange rate system and generally under assumptions different from ours; in particular, risk allocation is unimportant. Other contributions studying welfare properties of alternative exchange rate systems are Aizenman (1994), Buiter (2000), Chinn and Miller (1998), Sutherland (1995) and Cooper and Kempf(2004). In particular, Buiter (2000), and Cooper and Kempf (2004) argue against a monetary union when there are asymmetric shocks and only monetary policy is used for stabilization. Cooper and Kempf(2004) however stress that when also fiscal policy can be used, it is very hard to argue against a currency union on efficiency grounds. Sutherland (1995) considers efficiency properties of commitment to a band policy, versus either a fixed or fully flexible rate, using a Poole (1970) type of analysis where the variance of certain target variables is minimized. Many of the above papers assume full flexibility of prices and wages and thus do not directly follow the Mundell tradition. Price stickiness has been considered by Flood and Rose (1995), Obstfeld and Rogoff (1995, 1998), Devereux and Engel (1998, 1999), Rankin (1998) and Hau (1999); the latter paper also (as we do) assumes wage rigidity. In none of this work risk allocation plays any role for the government's optimal choice of exchange rate regime. $^{2}$

\footnotetext{
${ }^{2}$ The most closely related work in this respect is perhaps that of Huizinga (1997), on the political economy of exchange rate determination in a developing country, where the exchange rate can be overvalued in the political
} 
Our approach is unorthodox in several respects, first by focusing on the optimal exchange rate policy as a risk allocation device; secondly by deriving a target rule for the exchange rate, where the government's optimal exchange rate policy is affected by certain underlying fundamentals; and thirdly, by focusing completely on real variables.

We have made a few simplifications that limit the scope of our analysis, in particular, we do not study the case in which individuals can smooth their consumption by borrowing and lending in capital markets, and are instead assumed to always consume their current income, as is standard in the new open economy literature (Obstfeld and Rogoff(1996)). We do not either take into account possible government concerns about inflation. Nevertheless we believe that our approach may serve to emphasize and clarify the role of exchange rate policy in such a particular setting. In section 4 below we discuss some of our main assumptions further, and conclude that most results are likely to hold, under a wide range of alternative cases.

\section{The basic model}

Consider an economy where output is homogeneous and exported in its entirety, and a single consumption good is imported. The economy has a large and given number of identical firms operating in perfectly competitive markets. There is a given labor force L. The country is small and does not affect world market prices of export or import goods. ${ }^{3}$

The economy is stationary across periods. ${ }^{4}$ We assume that the economy in any period

equilibrium when the medial voter gains from low import prices; and Frenkel and Razin (1989), who stress the equivalence between exchange rate policy and tax policy when there may be "dual" exchange rates. The mechanisms by which distributional factors come into play, and the principles for determining the exchange rate, are here however quite different from ours.

\footnotetext{
${ }^{3}$ Not very much would change if firms were monopolistic competitors in world markets. Generally, optimal prices set by firms would still fluctuate procyclically, in the same way as under exogenous prices here, and be positively related to output, although not necessarily in exactly the same way as here.

${ }^{4}$ Stationarity here follows from the time-independence of all states.
} 
experiences one out of two possible states, 1 or 2 ; which can easily be generalized to an arbitrary number of states. In state $\mathrm{i}$ the world market prices of exports and imports are $\mathrm{p}_{\mathrm{i}}$ and $\mathrm{q}_{\mathrm{i}}$, respectively, $i=1,2$. Viewed ex ante the probabilities of state 1 and 2 occurring are $\beta$ and 1- $\beta$, respectively. ${ }^{5}$ In each state the government sets the exchange rate $z_{i}$, where an increase in $z_{i}$ implies a weakening of the home currency. Export goods are then sold abroad at a price of $p_{i} z_{i}$, and import goods are bought by the home country at a price of $\mathrm{q}_{\mathrm{i}} \mathrm{z}_{\mathrm{i}}$, both in terms of the home currency. The only role of government is to set the exchange rate. In the next section we will study the role of taxes or public expenditures. The current account is assumed to be balanced at all times.

In this model we will assume the following sequence of events. In period 1 , prior to the revelation of $p_{i}$ and $q_{i}$, the government announces nominal exchange rate $z_{i}, i=1,2$, for each of the two states that may occur. In period 1 a nominal, and state-invariant, wage $w$ is also agreed between private-sector agents. ${ }^{6}$ None of the results below depend on the exact level of w, only on some unemployment actually resulting in equilibrium, and the labor market thus does not clear given this wage, in neither of the states. The government's exchange rate regime announcement is assumed to be fully credible. In particular, the government is not allowed to set the nominal exchange rate after observing the nominal wage set by the private sector. In period 2 , the corresponding state (i.e. whether $\mathrm{i}$ equals 1 or 2 ) is revealed and the exchange rate $z_{i}$ is

\footnotetext{
${ }^{5}$ One difference between our approach and one where the stochastic variables (or their logs) follow timeindependent Brownian motion or Markov processes is that we will here have a "drift toward the mean" in the variables, while the alternative processes yield no systematic future movement of the state variable. We argue that our assumption is relevant in many situations, in particular when "long-run averages" are known with reasonable certainty; and when the short-run development of prices can be characterized by "business cycles" (with e.g. Brownian motion processes, the notion of "business cycles" is meaningless in the sense that one will have no idea of when the current state is "good" or "bad"). An extension of the current analysis to other stochastic processes must await future research.

${ }^{6}$ The wage may perhaps most naturally be viewed as set through wage bargaining.. The important thing here is however not the exact mechanism for setting the wage, but rather the property that wages are predetermined before the period-specific shock is realized so as to maintain a given average macro employment level.
} 
immediately determined in accordance to the government's commitment in period 1. Firms, taking the wage, all prices and the exchange rate as given, then determine output competitively. Note that this two-period basic model solution can be viewed as repeating over time, in identical fashion. Indeed, such repetition may be viewed as necessary for the government to establish credibility of its chosen rule, by observation of repeated adherence to this rule.

Firms have Cobb-Douglas production functions $\mathrm{L}^{\gamma}$ where $\gamma \in(0,1)$ is the elasticity of output with respect to labor (L) and also the factor share of labor under perfect competition. Firms' nominal profits in the home currency are given by:

$$
\pi_{i}=p_{i} z_{i} L_{i}^{\gamma}-w L_{i} \quad \mathrm{i}=1,2
$$

Firms maximize $\pi_{\mathrm{i}}$ with respect to employment $\mathrm{L}_{\mathrm{i}}$ in any given period, yielding the first-order conditions:

$$
p_{i} Z_{i} \gamma L_{i}^{-(1-\gamma)}=w \quad \mathrm{i}=1,2
$$

This leads to the labor demand equations:

$$
L_{i}=\gamma^{\frac{1}{1-\gamma}}\left(p_{i} Z_{i}\right)^{\frac{1}{1-\gamma}} w^{-\frac{1}{1-\gamma}} \quad \mathrm{i}=1,2
$$

yielding the following expression for firms' nominal profits:

$$
\pi_{i}=(1-\gamma) \gamma^{\frac{\gamma}{1-\gamma}}\left(p_{i} z_{i}\right)^{\frac{1}{1-\gamma}} w^{-\frac{\gamma}{1-\gamma}} \quad \mathrm{i}=1,2
$$

Assume a given number of perfectly competitive firms in the economy, normalized to one. Firm owners' utility of current profits is assumed to be as follows:

$$
U_{i}=\left(\frac{\pi_{i}}{q_{i} z_{i}}\right)^{\alpha}=(1-\gamma)^{\alpha} \gamma^{\frac{\alpha \gamma}{1-\gamma}} w^{-\frac{\alpha \gamma}{1-\gamma}} p_{i}^{\frac{\alpha}{1-\gamma}} q_{i}^{-\alpha} z_{i}^{\frac{\alpha \gamma}{1-\gamma}} \quad i=1,2
$$

Note that since $\mathrm{q}_{\mathrm{i}} \mathrm{z}_{\mathrm{i}}$ is the nominal price of the import good in terms of the home currency, the 
argument of the function (5) is the consumption value of profits. 1- $\alpha$ is the (constant) coefficient of relative risk aversion. We assume that $\alpha \in(0,1]$, i.e., firm owners are generally risk averse but may as a special case $(\alpha=1)$ be risk neutral.

Individual workers are similarly risk averse with (constant) coefficient of relative risk aversion equal to $1-\rho \in(0,1)$, and have following utility function preferences over the current real consumption value of wages:

$$
v_{i}=\left(\frac{w}{q_{i} z_{i}}\right)^{\rho} \quad \mathrm{i}=1,2
$$

From the point of view of the government, the sum of the labor force members' utilities is given by:

$$
V_{i}=L_{i}^{\delta}\left(\frac{w}{q_{i} z_{i}}\right)^{\rho}=\gamma^{\frac{\delta}{1-\gamma}} w^{-\left(\frac{\delta}{1-\gamma}-\rho\right)} p_{i}^{\frac{\delta}{1-\gamma}} q_{i}^{-\rho} z_{i}^{\left(\frac{\delta}{1-\gamma}-\rho\right)} \quad \mathrm{i}=1,2
$$

Here $L_{i}$ workers are employed, while $L-L_{i}$ unemployed; the latter have no current income in the model and thus by assumption zero utility. We will assume that $\delta \leq 1$. When $\delta=1$, the government preference function which represents all workers is said to be utilitarian, since $V_{i}$ then is the sum of the utilities of employed workers ( since as noted unemployed workers are assumed to have no income and thus zero utility). Holding the real wage of employed workers constant, $\delta<1$ would represent "decreasing returns" in the eyes of government, when employment increases. $\delta \in(\rho, 1)$ may imply that workers' individual utilities are still aggregated as before, but that a given reduction in unemployment is viewed as more gainful when employment at the outset is lower.

The government is assumed to be able and willing to commit to exchange rates $\mathrm{z}_{\mathrm{i}}$ in each of the possible future states, before the state is known. Here, the absolute levels of the exchange rates are unimportant for the solution of the model; only the relative exchange rates between the states matter. This follows because the wage is set simultaneously with or immediately following 
the government's commitment to future exchange rates, so as to achieve a given expected level of employment. In the formal analysis, we then only need to study the government's determination of relative exchange rates.

From (3), (5) and (7), the utilities of both workers and firms as groups are increasing in $\mathrm{z}$ as long as there is some unemployment. If the government follows a discretionary policy, it would then have an ex post incentive to set the exchange rate $z_{i}$ at a sufficiently high level for employment to be maximized. This would however violate not only the condition that the average real wage is given, but also the expectations of labor market participants. The other agents in the economy will anticipate this, and it may lead to non-optimal decisions (or a breakdown of the model). Full commitment to a given exchange rate policy is thus required.

In this light, the government can be viewed as maximizing the ex ante expected utility of the representative owner (EU), taking the expected utility of workers as a group (EV), and the expected real wage, as given. ${ }^{7}$ The Lagrangian for this problem can be written as:

$$
H=E U-\lambda E V=\beta U_{1}+(1-\beta) U_{2}-\lambda\left[\beta V_{1}+(1-\beta) V_{2}\right]
$$

$\mathrm{H}$ is maximized with respect to $\mathrm{z}_{1}$ and $\mathrm{z}_{2}{ }^{8}$ Taking logs, the two resulting equations can be expressed in the following way:

$$
(\delta-\alpha) \log p_{i}+[\delta-\alpha+(\alpha-\rho)(1-\gamma)] \log z_{i}+(\alpha-\rho)(1-\gamma) \log q_{i}=K, \mathrm{i}=1,2
$$

$\mathrm{K}$ is a constant and the same for both equations. Combining the two equations contained in (9) yields the following expression:

\footnotetext{
${ }^{7}$ Note the asymmetry following from the government (or its monetary authority) maximizing expected long-run utility taken as given that each firm maximizes short-run profits in each state. Thus the government is assumed not to have instruments that directly correct the inefficiencies that result from short-run behavior of firms, nor from workers decisions regarding wage setting.

${ }^{8}$ Note that the problem may equivalently be formulated as one where the utility of workers is maximized given firm owners' utility; or where the government maximizes an asymmetric Nash product of EU and EV respectively.
} 


$$
\log \left(\frac{z_{1}}{z_{2}}\right)=\frac{\delta-\alpha}{\delta-\alpha+(\alpha-\rho)(1-\gamma)} \log \left(\frac{p_{2}}{p_{1}}\right)+\frac{(\alpha-\rho)(1-\gamma)}{\delta-\alpha+(\alpha-\rho)(1-\gamma)} \log \left(\frac{q_{2}}{q_{1}}\right)
$$

(10) sums up, in a remarkably simple and intuitive way, the factors behind optimal exchange rate policy in this type of economy. It can be interpreted as an optimal risk allocation problem, between owners on the one hand, and workers on the other, when output is affected by short-run fluctuations in the exchange rate and export and import prices. It can be viewed as a generalized version of Borch's (1962) condition for optimal risk sharing between two parties signing a mutual and binding insurance contract. (10) can readily be generalized to an arbitrary number (or a continuum) of states, and is then a condition for comparing any two of these states. ${ }^{9}$

Interpreting (10) implies analyzing how the optimal exchange rate variation is determined and depends on the agents' degree of risk aversion and on the nature of the shocks affecting import and export prices. We will consider three main cases I-III.

\section{Case I. A shock that increases $p_{i}$ and $q_{i}$ proportionally}

Since the coefficients before $\log \left(\mathrm{p}_{2} / \mathrm{p}_{1}\right)$ and $\log \left(\mathrm{q}_{2} / \mathrm{q}_{1}\right)$ sum to one, the relative exchange rate, $\log \left(\mathrm{z}_{1} / \mathrm{z}_{2}\right)$, should in this case be adjusted equivalently, leaving import prices $\left(\mathrm{q}_{\mathrm{i}} \mathrm{z}_{\mathrm{i}}\right)$ and export prices $\left(\mathrm{p}_{\mathrm{i}} \mathrm{z}_{\mathrm{i}}\right)$ in terms of domestic currency, as well as output (and so employment), invariant to such shocks. This implies no real effects on the economy. "Real" and relative prices also remain unchanged even though all prices change simultaneously as a result of the "nominal" shock. A full opposite exchange rate adjustment should here exactly counteract such a shock.

\section{Case II. A shock that affects only relative export prices}

Here, only $\mathrm{p}_{2} / \mathrm{p}_{1}$ changes. A shock of this type can be interpreted either as a pure terms-of-trade

\footnotetext{
${ }^{9}$ The extension to more states is easily seen from (8), where we may simply introduce more states with individual probabilities attached to them (or a continuum of states with an associated probability measure).
} 
change, or as a shift in domestic productivity, i.e. a "real" shock. Recall our assumption that $\rho \leq \delta \leq 1$. We may here in turn identify four interesting subcases, A-D. Subcases A-C arise when workers are equally or more risk averse than the firms with respect to total income (i.e. $\alpha \geq \rho$ ).

\section{A: The exchange rate should adjust so as to leave export prices, $p_{\mathrm{i}} \mathrm{z}_{\mathrm{i}}$, (in terms of domestic currency) constant across states}

This is optimal only if workers and firms are equally risk averse with respect to income or there are constant returns in the production function. That is, either $\alpha=\rho$, or $\gamma \rightarrow 1$, respectively. (The coefficient before $\log \left(\mathrm{p}_{2} / \mathrm{p}_{1}\right)$ will then equal one.) Thus, when the two parties are equally risk averse or there are constant returns to scale (CRS) (though risk averse agents), it is optimal to keep output (and employment) constant across states, and let all uncertainty (all possible price fluctuations) be translated through a full variation of the import (and consumer) prices in the home currency, $\mathrm{q}_{\mathrm{i}} \mathrm{z}_{\mathrm{i}}$.

\section{B: The exchange rate should be kept fixed across states}

This is optimal only if the firm risk aversion coefficient equals the coefficient by which the government aggregates individual workers in the utility function, and workers are more risk averse than firms are. This holds when $\alpha=\delta>\rho$ (coefficient before $\log \left(\mathrm{p}_{2} / \mathrm{p}_{1}\right)$ will now equal zero) which implies that the government's welfare function aggregating up workers' utilities now exhibits more risk aversion with respect to wages than with respect to employment. The optimal solution for the exchange rate yields constant real wages across states. Producers then face the full variation in world market export prices, and adjust output accordingly and workers as a group will then absorb more risk through variations in employment. We will argue that this case is important as it provides a theoretical support for a monetary union. Note that it covers the 
important special case $\alpha=\delta=1$, where owners are risk neutral $(\alpha=1)$ and workers risk averse $(\rho<1)$, and all workers have the same weight in the government utility function representing them $(\delta=1)$

As long as $\rho<\alpha<\delta$ (the coefficient before $\log \left(\mathrm{p}_{2} / \mathrm{p}_{1}\right)$ is strictly between zero and one) we will have a solution intermediate between cases A and B. The optimal government policy will be to adjust the exchange rate so as to partly dampen the effects that a shock may have on output, consumer prices, and real wage across states. Recall that in comparison to the solution where $\mathrm{p}_{\mathrm{i}} \mathrm{Z}_{\mathrm{i}}$ is a constant, wages and consumer prices will vary much less. This will be definitely efficient when workers are more risk averse with respect to income variations than firms are $(\rho<\alpha)$, and more so the greater the difference in risk aversion, and the less risk averse firms are.

\section{$\mathrm{C}: \boldsymbol{\rho} \leq \boldsymbol{\delta}<\boldsymbol{\alpha}$}

Now the coefficient before $\log \left(\mathrm{p}_{2} / \mathrm{p}_{1}\right)$ in $(10)$ is negative. The exchange rate should then be appreciated when the terms of trade are weakened. Now efficient risk allocation implies opposite movements in employment and real consumer prices, and more volatile employment than under fixed exchange rates (which as noted would occur under case B). This is accomplished by further stimulating exports when there is an improvement in terms of trade. Intuitively, firms are now "nearly risk neutral". Profits can then be allowed to vary relatively more between states. Workers will however have their (individual and aggregate) utility affected in two different ways: With a reduction in the export prices, it is optimal to increase the individual worker real income. ${ }^{10}$ With an increase in export prices, it will instead be optimal to increase employment.

\footnotetext{
${ }^{10}$ Recall that the workers only consume foreign produced goods.
} 


\section{D: $\boldsymbol{\rho}>\boldsymbol{\alpha}$}

Here firms are more risk averse than workers. Then the coefficient before $\log \left(\mathrm{p}_{2} / \mathrm{p}_{1}\right)$ is greater than one. It is now particularly important to protect firms against risk, and firms' output (and employment) should fluctuate in the opposite direction to domestic import prices. This is accomplished by making the counteracting change in $z_{i}$ greater than the change in $p_{i}$, i.e. $\log \left(\mathrm{z}_{1} / \mathrm{z}_{2}\right)>\log \left(\mathrm{p}_{2} / \mathrm{p}_{1}\right)$. This $\underline{\text { reduces }}$ employment in the "good" state, while import (and domestic) prices in terms of the domestic currency are made to fluctuate by more than the exogenous fluctuation in export prices, also in terms of the domestic currency.

We will argue that cases $\mathrm{C}$ and $\mathrm{D}$ are less relevant than cases $\mathrm{A}$ and $\mathrm{B}$. For one thing, the model and its solutions are most easy to interpret and justify when $\delta=1$ and all workers count equally in the government's utility function. Then case $\mathrm{C}$ becomes irrelevant. Moreover, a main point of departure is that workers are more risk averse than firm owners, eliminating case $\mathrm{D}$. In the following we will accordingly concentrate on cases A and B.

\section{Case III. A shock that affects only relative import prices}

Since the coefficient in $(10)$ before $\log \left(\mathrm{q}_{2} / \mathrm{q}_{1}\right)$ is one minus the coefficient before $\log \left(\mathrm{p}_{2} / \mathrm{p}_{1}\right)$, the discussion concerning this coefficient is essentially the same as that concerning the latter coefficient, only with opposite sign. This coefficient is closer to one, the closer $\alpha$ is to $\delta$, but the same coefficient closer to zero the more similar the agents' risk preferences are $(\alpha=\rho)$ and the more responsive labor demand is to prices $(\gamma \rightarrow 1)$.

In summarizing the results, the following conditions speak in favor of relatively small or none exchange rate fluctuations:

- When there is a shock to export prices and firms' relative risk aversion coefficient 1- $\alpha$ is close to $1-\delta$. A special case is one in which all workers count equally in the government 
utility function $(\delta=1)$, this implies firm risk neutrality.

- When there is a shock to export prices and workers are highly risk averse with respect to income and more than firms.

- When there is a shock to import prices and the two parties are equally risk averse with respect to income.

- With a shock either to export or import prices, and when there are strongly decreasing returns to scale of the macro production function in labour (and correspondingly, the factor share of labour in GNP is relatively low).

Note here finally that the case of identical risk preferences is analytically identical to the standard case studied in most of the literature cited above, where a representative individual is considered. With fluctuations only in export prices, the exchange rate should then be adjusted perfectly to these prices, or kept fixed (enter a monetary union) when the import prices are the ones that fluctuate.

Let us summarise the most relevant results obtained from cases I - III in Table 1. 
Table 1

\begin{tabular}{|c|c|c|c|c|c|}
\hline & CASE I & \multicolumn{3}{|l|}{ CASE II } & CASE III \\
\hline \multirow[t]{2}{*}{ Change } & $\Delta \log \left(\mathrm{p}_{2} / \mathrm{p}_{1}\right)=$ & \multicolumn{3}{|c|}{$\Delta \log \left(\mathrm{p}_{2} / \mathrm{p}_{1}\right)=\phi ; \Delta \log \left(\mathrm{q}_{2} / \mathrm{q}_{1}\right)=0$} & $\Delta \log \left(\mathrm{p}_{2} / \mathrm{p}_{1}\right)=0$ \\
\hline & & $\begin{array}{l}\alpha=\rho \text { and } \gamma \rightarrow 1 \\
\text { (but } \alpha \geq \rho \text { ) }\end{array}$ & $\alpha=\delta(=1)>\rho$ & $\alpha<\rho$ & $\alpha=\rho ; \gamma \rightarrow 1$ \\
\hline $\begin{array}{l}\text { Effects on } \\
\text { exchange } \\
\text { rate and } \\
\text { other } \\
\text { variables }\end{array}$ & $\Delta \log \left(\mathrm{z}_{1} / \mathrm{z}_{2}\right)=\phi$ & $\begin{array}{l}\mathrm{p}_{1} \mathrm{z}_{1}=\mathrm{p}_{2} \mathrm{z}_{2} \\
\mathrm{q}_{\mathrm{i}} \mathrm{z}_{\mathrm{i}} \text { vary } \\
\text { a lot, } \forall \mathrm{i} \\
\Delta \log \left(\mathrm{z}_{1} / \mathrm{z}_{2}\right)=\phi\end{array}$ & $\begin{array}{l}\mathrm{w} / \mathrm{q}_{\mathrm{i}} \mathrm{z}_{\mathrm{i}} \text { stable } \\
\Delta \log \left(\mathrm{z}_{1} / \mathrm{z}_{2}\right)=0 \\
\mathrm{~L}_{\mathrm{i}}, \mathrm{p}_{\mathrm{i}} \mathrm{z}_{\mathrm{i}} \text { vary a } \\
\text { lot, } \forall \mathrm{i}\end{array}$ & $\begin{array}{l}\log \left(\mathrm{p}_{2} / \mathrm{p}_{1}\right)> \\
\log \left(\mathrm{z}_{1} / \mathrm{z}_{2}\right) \\
\mathrm{z}_{\mathrm{i}} \mathrm{p}_{\mathrm{i}}<\mathrm{z}_{\mathrm{i}} \mathrm{q}_{\mathrm{i}} .\end{array}$ & $\begin{array}{l}{\left[\operatorname{But} \Delta \log \left(\mathrm{z}_{1} / \mathrm{z}_{2}\right)\right.} \\
=\phi \text { if } \alpha=\delta]\end{array}$ \\
\hline
\end{tabular}

\section{Extensions of the basic model}

\subsection{Wage indexation}

We have so far assumed that the wage is nominally fixed in any given period. Alternatively, assume that the wages are determined such that there is still unemployment in each period, but the wage is adjusted (imperfectly) ex post to unexpected changes in workers' cost of living. This can be represented by a wage indexation scheme of the following form:

$$
w=w_{0}\left(q_{i} z_{i}\right)^{\theta} \quad \mathrm{i}=1,2
$$

Here $\mathrm{w}_{0}$ is a base wage (similar to $\mathrm{w}$ in section 2 above), and $\theta$ a parameter indicating the degree of indexation. ${ }^{11}$ When $\theta=0$ there is no indexation and we are back to the model already analyzed above. When $\theta=1$, by contrast, there is full indexation and workers' real wages are kept

\footnotetext{
${ }^{11}$ Note however that when $\theta>0$, the level of $\mathrm{w}_{0}$ will generally not correspond to the level of $\mathrm{w}$ in section 2 above, assuming that workers' wage demands are set so as to maintain a given (average) utility level of employed workers. This feature will however in no way affect any of the basic results from the model.
} 
invariable across states. $\theta \in(0,1)$ represents intermediate cases where values closer to unity imply relatively greater degrees of indexation.

The labor demand equations equivalent to (3) can now be written as follows:

$$
L_{i}=\gamma^{\frac{1}{1-\gamma}} w_{0}^{-\frac{1}{1-\gamma}} p_{i}^{\frac{1}{1-\gamma}} q_{i}^{-\frac{\theta}{1-\gamma}} z_{i}^{\frac{1-\theta}{1-\gamma}} \quad \mathrm{i}=1,2
$$

Correspondingly, the expression for firms' utility of current profits, replacing (5), is:

$$
U_{i}=\left(\frac{\pi_{i}}{q_{i} z_{i}}\right)^{\alpha}=(1-\gamma)^{\alpha} \gamma^{\frac{\alpha \gamma}{1-\gamma}} w_{0}^{-\frac{\alpha \gamma}{1-\gamma}} p_{i}^{\frac{\alpha}{1-\gamma}} q_{i}^{-\frac{\alpha}{1-\gamma}[1-\gamma(1-\theta)]} z_{i}^{\frac{\alpha \gamma(1-\theta)}{1-\gamma}} \quad \mathrm{i}=1,2
$$

The government's aggregate of workers' utilities, replacing (7), is likewise given by:

$$
V_{i}=L_{i}^{\delta}\left(\frac{w}{q_{i} Z_{i}}\right)^{\rho}=\gamma^{\frac{\delta}{1-\gamma}} w_{0}^{-\left(\frac{\delta}{1-\gamma}-\rho\right)} p_{i}^{\frac{\delta}{1-\gamma}} q_{i}^{-\rho(1-\theta)-\frac{\theta \delta}{1-\gamma}} z_{i}^{\left(\frac{\delta}{1-\gamma}-\rho\right)} \quad \mathrm{i}=1,2
$$

We may now also derive a new expression for optimal government exchange rate determination, equivalent to (10), as follows:

$$
\log \left(\frac{z_{1}}{z_{2}}\right)=\frac{\delta-\alpha}{(1-\theta)[\delta-\alpha+(\alpha-\rho)(1-\gamma)]} \log \left(\frac{p_{2}}{p_{1}}\right)+\frac{(\alpha-\rho)(1-\gamma)(1-\theta)-(\delta-\alpha) \theta}{(1-\theta)[\delta-\alpha+(\alpha-\rho)(1-\gamma)]} \log \left(\frac{q_{2}}{q_{1}}\right)
$$

The main interesting change implied by wage indexation comes via the term $1-\theta$ in the denominator of the expression (15), before $\log \left(\mathrm{p}_{2} / \mathrm{p}_{1}\right)$ and $\log \left(\mathrm{q}_{2} / \mathrm{q}_{1}\right)$. This term implies that the optimal variation in the exchange rate under the case of an indexed wage, is greater than the equivalent variation under a fixed wage. In other words, the greater the degree of indexation, the greater is the optimal variation in the exchange rate, when only export prices change. The intuitive explanation of this result can be found from inspection of the expressions (13) and (14), for the utilities of firms and workers respectively as viewed by the government. In both 
expressions, the exponent to $z_{i}$ enters with a factor $1-\theta$, implying that variations in $\mathrm{z}$ are now less efficient as a means of affecting the respective utilities. With given risk aversion parameters, a greater variation in $\mathrm{z}$ is then required in order to achieve a given allocation of risk between the two groups across states, in response to a given variation in export or import prices. It is consequently necessary for the government to vary the exchange rate by more in order to leave workers and firm owners equally well off. ${ }^{12}$ With greater wage indexation, the exchange rate becomes a less powerful mechanism for achieving an efficient allocation of risk between workers and owners. Greater changes in the exchange rate between states are then required to achieve a given (optimal) intertemporal risk allocation.

In the special cases where the solution in section 2 above was to keep the exchange rate fixed, nothing is changed by indexation (case B above). Moreover, when export and import prices change proportionally (a "monetary" shock) the exchange rate should still, as in section 2, be changed in this same proportion, again leaving all real variables constant.

Note also that if the government faces a choice between a fixed-exchange-rate scheme and a variable one, this choice is in our model not affected by the degree of indexation. The reason is that the optimal risk and output allocation are independent of the degree of indexation. Indexation only affects the variability of nominal prices and wages, and not the variability of real prices for consumers and producers. Thus the utilities from solutions with fixed and optimally variable exchange rates, as viewed by the government, are the same whether this latter exchange rate varies little and the wage is totally rigid, or whether the exchange rate varies substantially under wage indexation.

\footnotetext{
${ }^{12}$ Another related intuitive explanation is that when there are changes in export prices only, the model in section 2 above yields an optimal tradeoff between productive allocation (variations in labor input) and risk allocation. As long as risk aversion coefficients and labor demand are unaltered, this optimal tradeoff is not changed by the introduction of indexation, requiring a greater adjustment in $\mathrm{z}$ when wages are indexed.
} 


\subsection{Taxation}

In practice the government has other mechanisms than exchange rate variations available, for affecting the riskiness of wage and profit income. As pointed out by a number of authors, such as Varian (1980), Agell (1992), and Bertola and Koeniger (2004), the tax system may play such a role. We will here extend our basic model above, that is without indexation, to a case where profit and wage incomes are subject to taxation, and the possibility that tax rates may differ between states. We here study optimal exchange rate variation for given tax rates: the government is thus not assumed to maximize its objective function with respect to the latter. ${ }^{13}$ Assume that after-tax profit income for owners is given by (modifying (5)):

$$
U_{i}=\left(\frac{\tau_{i} \pi_{i}}{q_{i} z_{i}}\right)^{\alpha} \quad \quad \mathrm{i}=1,2
$$

where $1-\tau_{i}$ is a state-specific tax parameter for each of the states $i=1,2$, used by the government to affect the general profit level in each of the two period types. Similarly, assume that after-tax real wages are given by (modifying (6)):

$$
v_{i}=\left(\frac{\eta_{i} w}{q_{i} z_{i}}\right)^{\rho} \quad \mathrm{i}=1,2,
$$

where $1-\eta_{i}$ are tax parameters affecting real net wage income. Increases in $\tau_{\mathrm{i}}$ and $\eta_{\mathrm{i}}$ then imply that the respective state-contingent profit or wage tax is lowered. We can here assume that the government adjusts the levels of taxes in such a way that net expected tax revenue is exactly zero (which implies that some of the tax rates will be negative). We now find a new formula for optimal exchange rate determination, similar to (10):

\footnotetext{
${ }^{13}$ We thus do not address the issue of how tax revenue is spent, or how large it is. Since only relative tax rates matter for the solution to the model, we may here assume that the absolute rates are adjusted such that expected overall tax revenue is kept at a constant level, possibly at zero.
} 


$$
\begin{aligned}
& \log \left(\frac{z_{1}}{z_{2}}\right)=\frac{\delta-\alpha}{\delta-\alpha+(\alpha-\rho)(1-\gamma)} \log \left(\frac{p_{2}}{p_{1}}\right)+\frac{(\alpha-\rho)(1-\gamma)}{\delta-\alpha+(\alpha-\rho)(1-\gamma)} \log \left(\frac{q_{2}}{q_{1}}\right) \\
& -\frac{\alpha(1-\gamma)}{\delta-\alpha+(\alpha-\rho)(1-\gamma)} \log \left(\frac{\tau_{2}}{\tau_{1}}\right)+\frac{\rho(1-\gamma)}{\delta-\alpha+(\alpha-\rho)(1-\gamma)} \log \left(\frac{\eta_{2}}{\eta_{1}}\right)
\end{aligned}
$$

The way, in which the rule for setting relative exchange rates is changed, is now affected by the state-dependent variation in average tax rates $1-\tau_{\mathrm{i}}$ and $1-\eta_{\mathrm{i}}$. It may here be reasonable to assume that the government uses the tax system to smooth real wage income but not profits across states. We will in turn consider both cases. Notice that profits and wage income for each employed worker change across states for given exchange rates when import prices q change; while when export price changes, only profits will be exposed to additional variation. Consider then the case where $\mathrm{q}_{2}>\mathrm{q}_{1}$ such that real wage and profit incomes are lower in state 2 . The government would naturally counteract the effect of a higher $\mathrm{q}_{2}$ on the workers' income by decreasing their taxes in the second state. This implies setting $\eta_{2} / \eta_{1}>1$, making the $\log \left(\eta_{2} / \eta_{1}\right)$ positive. ${ }^{14}$ We see that in general this is likely to increase the optimal variation in the exchange rate (i.e. the exchange rate in state 2 is going to be much lower than in state 1 ), and more so the larger $\eta_{2}$ becomes in comparison to $\eta_{1}$. Thus, a larger appreciation of the exchange rate will occur as a result of $a$ tax relief and of the risk sharing mechanism. These two will just more than compensate the loss in real income due to an increase in import prices. Note however that if the exchange rate in state 2 is allowed to appreciate a great deal (at least relatively to the exchange rate that will prevail in state1), it will create a large swing in export incomes and so in profits to the capitalists. Profits can be smoothed by a combination of exchange rate changes and tax changes such as $\tau_{2} / \tau_{1}>1$. In fact, the exchange rate will vary less if the government implements procyclical profit taxes. Intuitively, from (18) we can see that for fixed taxes to the workers and export prices, if the

\footnotetext{
${ }^{14}$ Note that $\tau \pi$ and $\eta w$ are the capitalists' and workers' incomes after tax, respectively. Thus, a lower $\tau$ or $\eta$
} 
$\log \left(\mathrm{q}_{2} / \mathrm{q}_{1}\right)$ increases and $\log \left(\tau_{2} / \tau_{1}\right)$ does so less than proportionately ${ }^{15}$, there will be a lower increase in $\log \left(\mathrm{z}_{1} / \mathrm{z}_{2}\right)$ than would otherwise occur if no tax relief was implemented for exporters. Note that in the interesting and special case where $\log \left(\mathrm{q}_{2} / \mathrm{q}_{1}\right)=\log \left(\tau_{2} / \tau_{1}\right)=\log \left(\eta_{2} / \eta_{1}\right)$ (i.e., the retained shares of incomes after tax for both owners and workers are changed in proportion to import prices), the exchange rate should be kept constant.

Introducing new government instruments through taxes opens up a new and very interesting perspective in the model, namely the issue of what variations in tax rates are optimal for a given exchange rate target. Consider in particular a fixed exchange rate, which is the obvious "target" under a monetary union. We see that equation (18) can easily be fulfilled for $\mathrm{z}_{1} / \mathrm{z}_{2}$ constant, and $\mathrm{p}_{2} / \mathrm{p}_{1}$ and/or $\mathrm{q}_{2} / \mathrm{q}_{1}$ changing, by adjusting the relative tax rates appropriately. We have just analysed this above, for the case of variation in import prices alone. The same analysis can be done when export prices vary, as when $\log \left(\mathrm{p}_{2} / \mathrm{p}_{1}\right)$ increases and the coefficient before $\log \left(\mathrm{p}_{2} / \mathrm{p}_{1}\right)$ is positive. Complementary policy rules, such as either a countercyclical variation in the profit tax rate, or a procyclical variation in the wage tax rate, can thus affect the optimal exchange rate fluctuations in different ways. Achieving a stable, and at the same time optimal, exchange rate may here be implemented through either a procyclically variable wage tax, which should be higher in the state with high export prices, or a countercyclical profit tax, which is reduced when import prices are high.

\subsection{Imperfect competition}

In the analysis above all prices are assumed to be given in the world market. Ceteris paribus, perfect competition will allow international price changes to pass on perfectly to domestic

\footnotetext{
implies lower taxes collected by the government.

${ }^{15}$ Notice that if the $\log \left(\tau_{2} / \tau_{1}\right)$ increases in the same proportion as the $\log \left(\mathrm{q}_{2} / \mathrm{q}_{1}\right)$, it can result in an appreciation of the exchange rate in the state 2 . Reasonably, if producers are going to get equally (or more than) compensated with lower taxes when import prices go up, they will have to face an appreciation of the exchange rate in state 2.
} 
consumer and producer markets. In many practical cases the assumption of perfect competition will be violated for several reasons. This is likely to be the case when domestic exporters sell in consumer brand markets with differentiated products, as analyzed e.g. in the seminal paper by Dixit and Stiglitz (1977), and when a country specializes (almost) fully on the production of one or a few goods, producers may behave monopolistically instead of competitively. ${ }^{16}$

We will in this section extend our basic model to encompass the case of monopolistic producers in the export sector. Assume then that instead of (1), firms' profits are given by

$$
\pi_{i}=p_{i} L_{i}^{-\sigma \gamma} z_{i} L_{i}^{\gamma}-w L_{i}, \quad \mathrm{i}=1,2
$$

where $\mathrm{p}_{\mathrm{i}}$ now may be interpreted as a fixed parameter in the (world) demand function for export goods, and $\sigma$ is the (absolute value of the) elasticity of the export price with respect to production in the export sector, which is the inverse of the elasticity of world market demand for the home good with respect to export prices, where $0<\sigma<1$. Except for (1a), the model is the same as that in section 2 . We can then simply replace $\gamma$ in that version of the model, by $\gamma(1-\sigma)$ in the current version, and everything else remains the same. Notice that $\gamma(1-\sigma)$ will always be positive. The formula for optimal exchange rate variation becomes

$$
\log \left(\frac{z_{1}}{z_{2}}\right)=\frac{\delta-\alpha}{\delta-\alpha+(\alpha-\rho)(1-\gamma(1-\sigma))} \log \left(\frac{p_{2}}{p_{1}}\right)+\frac{(\alpha-\rho)(1-\gamma(1-\sigma))}{\delta-\alpha+(\alpha-\rho)(1-\gamma(1-\sigma))} \log \left(\frac{q_{2}}{q_{1}}\right)
$$

This is a simple extension of the formula (10) in section 2. Considering the standard case where both coefficients before $\log \left(\mathrm{p}_{2} / \mathrm{p}_{1}\right)$ and $\log \left(\mathrm{q}_{2} / \mathrm{q}_{1}\right)$ are positive, the effect of imperfect competition

\footnotetext{
${ }^{16}$ In fact monopolistic competition does not depend on producers being large, but only on them being specialized given that products are differentiated (which is not the case in our model). It is however generally clear those larger producers will have more power to determine their own prices. See Helpman and Krugman (1991) for discussion of such issues.
} 
is seen to be a relative increase in the weight of $\log \left(\mathrm{q}_{2} / \mathrm{q}_{1}\right)$, and a relative decrease in that of $\log \left(\mathrm{p}_{2} / \mathrm{p}_{1}\right)$. Thus in particular, when only export demand fluctuates, the exchange rate response to such fluctuations ought to be even smaller, than in our basic model of section 2. Moreover, when there is a shock affecting $p_{2}$ causing upward shift in the demand function for exports (i.e. $p_{2} L_{2}^{-\gamma \sigma}$ shifs up), greater monopoly power (measured by $\sigma$ ) implies lower variation in the exchange rate (i.e. $z_{2}$ will not change a lot with respect to $z_{1}$ ). Intuitively, the output response to such demand fluctuations is now smaller, and this is the reason why there will be less of a need to adjust the exchange rate (i.e. revaluing in the good state will be that large). In this sense, the monopolistic case strengthens our basic case for a relatively invariable exchange rate. Finally, one could add that under monopoly conditions, wage and profit taxes can be additionally implemented to ameliorate the effect of monopoly power on the low degree of pass-through.

\section{Conclusions and discussion}

We have derived an optimal rule for the exchange rate when future states are uncertain and the nominal wage is either fully rigid in the short run, or partly indexed to the nominal exchange rate. The main role of the exchange rate in our model is to allocate risk optimally between two groups in the economy, workers and owners. We find that when nominal export and import prices change proportionately in response to the occurrence of a shock, the government should adjust the relative exchange rate to leave all domestic variables constant. With stochastic sectoral ("real") shocks where import prices are likely to vary (perhaps considerably) less than export prices, if wages are fixed in the short run (as in section 2) and both workers and owners are risk averse but workers more so, the exchange rate should be allowed to appreciate in response to a positive shock to export prices alone. Such appreciation should be only partial in the sense that home and world market export prices should move in the same direction. 
The exchange rate should adjust fully (and leave home export prices constant) only when workers and firm owners have equal degrees of relative risk aversion. In another important practical case, with risk neutral owners and risk averse workers (and utilitarian government preferences representing workers), the exchange rate should be kept constant.

Section 3 studies three different extensions to the basic model. First, when wages are partially indexed to the nominal consumer price level ex post, as studied in subsection 3.1, the exchange rate should generally vary more, while neither real variables nor the choice between a fixedversus variable-rate regime is affected by wage indexation. Secondly, in subsection 3.2 we study the effects of state-variable wage and profit taxes. We here show that such taxes modify the optimal exchange rate rule, in particular by making the exchange rate less sensitive to export prices (import prices) changes when wage taxes (profit taxes) move procyclically (countercyclically). We here also note that a fixed exchange rate can now be implemented as the optimal rate, by varying tax rates appropriately, thus strengthening the case for a monetary union under cases where individual countries have the possibility of independent tax policies. The third extension, in subsection 3.3, deals with imperfect competition for exporters. The main effect of imperfect competition for optimal exchange rate policy is to further reduce the variability of exchange rate fluctuations when export demand fluctuates, as output fluctuations in this case are typically dampened relative to the competitive case.

We have above argued that "real" shocks to the economy on the average imply less variation in import prices than in export prices. This assumption has at least two justifications. First, efficient production in a small open economy is likely to imply that exports are concentrated to a relatively small range of goods, while imports are likely to be much more diversified. ${ }^{17}$ Independent fluctuations in relative prices among foreign goods might then largely cancel out for

\footnotetext{
${ }^{17}$ Such an argument could clearly justify multiple-equilibrium outcomes of a sort similar to those analyzed by Frankel and Rose (1998) and Corsetti and Pesenti (2002). The idea here is that integration into a monetary union
} 
the composite of imports, but not for the composite of exports. The other justification is that fluctuations in $p_{i}$ can be interpreted (wholly or partly) as domestic productivity shocks. Such shocks would lead to greater fluctuations in $\mathrm{p}_{\mathrm{i}}$, but in $\mathrm{q}_{\mathrm{i}}$ only when consumer goods in question are produced domestically.

The more traditional "representative individual" case arises in our model when owners and workers have the same risk preferences. In the no-indexation case, given fluctuations in export prices alone, the exchange rate should then adjust fully to these in the short run, and optimal responses are the same to price shocks as to "real" shocks. Moreover, the more consumer prices covary with export prices, the less should the exchange rate adjust. In our case by contrast, distinguishing between risk neutral owners and risk averse workers, results are very different. We thus demonstrate that the rather plausible issue, of differential risk preferences between workers and firm owners, may matter greatly for the optimal exchange rate rule.

It should be stressed that our derived solution provides an optimal commitment rule that the government prefers to announce, and be able to follow even after the respective state has been revealed. When this optimal rule implies "very small” or zero fluctuations in the exchange rate, the model can be argued to give a theoretical justification for a monetary union between the countries to which the model applies. Alternatively, an exchange rate band could be viewed as a mechanism for committing to small but nonzero exchange rate fluctuations. ${ }^{18}$

As noted, our analysis is based several assumptions which may need further discussion. The following discussion should also serve as a scope for future research.

i) Individuals in the economy are divided into two well-defined groups, workers and owners. This assumption drives many of our interesting results. Most modern approaches to

could promote intra-industry specialization, which in turn leads to greater fluctuations in $\mathrm{p}_{2} / \mathrm{p}_{1}$.

${ }^{18}$ In the multi-state case, a currency band can only directly determine the maximum variation in the exchange rate and not the optimal relative rate associated with each state. It may still then perhaps be viewed as an acceptable approximation to the optimal solution. 
international macroeconomics (as represented e.g. by Obstfeld and Rogoff (1996)) take the representative agent approach whereby this issue is by definition excluded. Our justification is the empirical observation that workers (at least in most European countries) largely hold their wealth in their own human capital and to some degree in residential capital, while owners and managers to a much greater extent hold their wealth in production and financial capital. In most European countries, workers own a relatively small fraction of corporate stock. ${ }^{19}$ Fluctuations in household wealth can then overwhelmingly be represented by fluctuations in real wages (and by fluctuations in the value of home equity, which is typically correlated with average wages), while for owners and managers much more of wealth depends on business values. Most of workers' wealth is also largely undiversifiable (e.g. financial equities such as stocks and bonds cannot be issued on the basis of human capital), while owners/manager wealth can much more easily be diversified. This should imply that workers are more risk averse than owners. On the other hand, more diversified wealth across groups of individuals should imply more equal risk preferences. This will in case have consequences for the optimal exchange rates, in accordance with comments made above.

ii) No market for foreign exchange. Such a market would make it more difficult for the government to manage the exchange rate as prescribed by the solution to our model, since speculation tends either to drive the equilibrium exchange rate to its expectation over all possible ex post states, or it implies that compensating interest rate differentials between countries are required. This is likely to be a more serious problem the greater are the "optimal" exchange rate fluctuations between states. This however reinforces the criteria for committing to a monetary

\footnotetext{
${ }^{19}$ True, in some countries such as Norway the authorities have tried to stimulate more widespread stock ownership through tax reductions for limited quotas of annual mutual-fund investments. Still the overall fraction of stock owned in this way is relatively small, and labor unions remain overall sceptical toward such ownership. In addition pension funds, which in principle represent future benefits of workers, are large stockholders in many countries. The latter should represent no principal problem in our model since pension fund returns do not affect the short-run consumption possibilities of workers, given that workers cannot borrow with future pension
} 
union.

\section{iii) There is no market for savings and other financial instruments for smoothing real}

income. This is clearly unrealistic, and an unattractive assumption to many economists. Arguably, however, not all risk can be eliminated through these types of markets, in particular not for workers. Workers' incomes, and consumption possibilities, stem from their sale of human capital services, which are generally not fully insurable. A large body of empirical evidence supports this view, much of it from the U.S. where financial markets of this sort are most developed and available in practice to ordinary workers. Mankiw (2000) and Seidman (2001) review this literature, and find that consumption is highly correlated with current income, much more than one should expect if households actually used efficient financial markets for consumption smoothing. ${ }^{20}$ These results can follow from either imperfect capital markets, or simply an inability of households to actually smooth consumption, or both. In any case, there may clearly be room for active income-smoothing policies by the government, and a fixed exchange rate may serve exactly such a role here. Firm owners should also clearly have greater possibilities for smoothing consumption relative to current earnings, both because they likely face fewer frictions in the relevant financial markets and because owners are likely to have more savings available for immediate consumption.

iv) All output is exported while all consumption is imported. This assumption involves two different aspects. First, all goods are assumed to be tradables. A more traditional approach in the recent literature is to assume a tradable and nontradable sector (as in Obstfeld and Rogoff(1995, 1998), Devereux and Engel $(1998,1999)$ and Hau (2000), in the context of two-country models).

payments as collateral.

${ }^{20}$ Among important studies showing this are Campbell and Mankiw (1989), Shapiro and Slemrod (1995), Parker (1999) and Souleles (1999). In fact, Campbell and Mankiw (1989) estimate that approximately half of all wage income in the U.S. goes to households that consume according to current income, and half to households that consume according to permanent income (as would result with effectively functioning financial markets). 
Generally, a nontradable sector should tend to smooth consumption when the variation in $\mathrm{p}$ is interpreted as a terms-of-trade shock, but not necessarily when it is interpreted as a productivity shock that also comprises the nontradable sector itself. Secondly, it implies that the country itself produces no export goods that are also imported. A straightforward alternative is here to assume that the country's export goods constitute a certain fraction of its import goods. This can in the model be represented by a positive correlation between import and export prices, such that import prices change in the same direction but by less than export prices. A likely effect is then a greater optimal variation in the exchange rate than that found above (in particular when the optimal rule above implies small exchange rate variations).

\section{v) The exchange rate is pre-set by a monetary authority to optimise a long-run} intertemporal utility function withoug facing credibility problems. In the optimization sense, the model is "normative" rather than positive, in attempting to say what the government ought to do, not necessarily what the government actually does. Absent a currency union credibility problems will always be present, in part because a country's government is likely to change from time to time. It could be relevant to take such credibility issues more directly into consideration the model, when discussing the desirability of whether or not join a currency union. While this must be a topic for further work, such additional arguments appear to favor a currency union, relative to the analysis presented above. Another issue for future work is whether a monetary authority, through its exchange rate policy or possibly in coordination with other government policies, may be able to affect real wages and thereby average employment more directly.

Finally, one may consider the relationship between the results from the current model with a more traditional discussion of possible reasons for wanting an independent monetary policy, based on the idea of asymmetric shocks. Asymmetric supply shocks can here be interpreted as 
idiosyncratic shocks to export prices, while asymmetric demand shocks can in our model rather be identified with shocks to import prices. ${ }^{21}$ Given these interpretations, the exchange rate should here be kept "roughly" constant in view of supply shocks, but possibly vary more when shocks are demand-related. This conclusion is somewhat at odds with "conventional wisdom" as expressed e.g. in the traditional "optimum currency area" literature referred to above, and is more in line with recent arguments, e.g. Buiter $(1997,2000) .{ }^{22}$ Our analysis thus supports, and gives a new dimension to, such a distinction.

\section{References}

Agell, J. (2002), On the determinants of labour market institutions. German Economic Review, $3,107-135$.

Aizenman, J. (1994), Monetary and real shocks, productive capacity and exchange-rate regimes. Economica, 407-434.

Aizenman, J. and Frenkel, J. A. (1985), Optimal wage indexation, foreign exchange intervention and monetary policy. American Economic Review, 75, 402-423.

Alesina, A., Barro, R. J. and Tenreyro, S. (2002), Optimal currency areas. Harvard Institute of Economic Research Discussion Paper, 1958.

Artis, M. and Currie, D. (1981), Monetary targets and the exchange rate: A case for conditional targets. In W. Eltis and P. Sinclair (eds.): The money supply and the exchange rate, 176-200. Oxford University Press.

Azariadis, C. and Stiglitz, J. E. (1983), Implicit contracts and fixed-price equilibria. Quarterly Journal of Economics, 98 (supplement), 1-22.

Barro, R. J. and Gordon, D. B. (1983), Rules, discretion and reputation in a model of monetary policy. Journal of Monetary Economics, 12, 101-121.

Bertola, G. and Koeniger, W. (2004), Consumption smoothing and the structure of labor and credit markets. IZA discussion paper 1052.

\footnotetext{
${ }^{21}$ The idea here is that a demand shock can be assumed to take the form of an exogenous increase in the need for imports, which could have the same real effects on the economy as an increase in import prices.

${ }^{22}$ As discussed in the recent paper by Cooper and Kempf (2004), this conclusion can in principle be overturned when fiscal policy can be used actively and systematically to counteract country-specific shocks. This is a further interesting topic for future research, within the context of the present model.
} 
Borch, K. (1962), Equilibrium in a reinsurance market. Econometrica, 30, 424-444.

Buiter, W. H. (1997), The economic case for monetary union in the European union. Review of International Economics, 5 (supplement), 10-35.

Buiter, W. H. (2000), Optimal currency areas: Why does the exchange rate regime matter? CEPR discussion paper, no. 2366.

Campbell, J. and Mankiw, G. N. (1989), Consumption, income, and interest rates: Reinterpreting the time series evidence. NBER Macroeconomics Annual, 185-216. Cambridge, Ma.: MIT Press.

Chinn, D. M. and Miller, P. J. (1998), Fixed vs. floating rates: A dynamic general equilibrium analysis. European Economic Review, 43, 1221-1249.

Cooper, R. amd Kempf, H. (2004), Overturning Mundell: Fiscal policy in a monetary union. Review of Economic Studies, 71, 371-396.

Corsetti, G. and Pesenti, P. (2001), International dimensions of optimal monetary policy. NBER working paper, no. 8230.

Corsetti, G. and Pesenti, P. (2002), Self-validating optimum currency areas. NBER working paper, no. 8783 .

Devereux, M. B. and Engel, C. (1998), Fixed vs. floating exchange rates: How price setting affects the optimal choice of exchange-rate regime. Working paper, University of Washington.

Devereux, M. B. and Engel, C. (1999), The optimal choice of exchange-rate regime: Pricesetting rules and internationalized production. NBER working paper, no. 6992.

Devereux, M. B. and Engel, C. (2000), Endogenous currency and price setting in a dynamic open economy model. NBER working paper, no. 8559.

Dixit, A. and Stiglitz, J. E. (1977), Optimum product variety. American Economic Review, 67

Flood, R. P. (1979), Capital mobility and the choice of exchange rate regime. International Economic Review, 20, 405-416.

Flood, R. P. and Marion, N. P. (1982), The transmission of disturbances under alternative exchange-rate regimes with optimal indexing. Quarterly Journal of Economics, 96, 43-66.

Flood, R.P. and Rose, A. K. (1995), Fixing exchange rates: A virtual quest for fundamentals. The Journal of Monetary Economics, 36, 3-37.

Frankel, J. A. and Rose, A. K. (1997), The endogeneity of the optimum currency area criteria. Swedish Economic Policy Review, 4, 487-512.

Frankel, J. A. and Rose, A. K. (1998), The endogeneity of the optimum currency area criteria. Economic Journal, 108, 1009-1025. 
Frenkel, J. and Razin, A. (1989), Exchange-rate management viewed as tax policies. European Economic Review, 33, 761-781.

Fukuda, S. and Hamada, K. (1987), towards the implementation of desirable rules of monetary coordination and intervention. Working paper, Yale University.

Glick, R. and Wihlborg, C. (1990), Real exchange rate effects of monetary shocks under fixed and flexible exchange rates. Journal of International Economics, 28, 267-290.

Hamada, K. and Sakurai, K. (1978), International transmission of stagflation under fixed and flexible exchange rates. Journal of Political Economy, 86, 877-895.

Hau, H. (1999), Exchange rate determination: The role of factor prices and market segmentation. Journal of International Economics, forthcoming.

Hau, H. (2000), Real exchange rate volatility and economic openness: Theory and evidence. CEPR working paper, no. 2356.

Helpman, E. and Krugman, P. (1991), Market structure and international trade. Cambridge, Ma.: MIT Press.

Helpman, E. and Razin, A. (1982), A comparison of exchange rate regimes in the presence of imperfect capital markets. International Economic Review, 23, 365-388.

Huizinga, H. (1997), Real exchange rate misalignment and redistribution. European Economic Review, 41, 259-277.

Lucas, R. E. (1982), Interest rates and currency prices in a two-country world. Journal of Monetary Economics, 10, 335-359.

Magill, M. and Quinzi, M. (1996), Theory of incomplete markets. Cambridge, Ma.: MIT Press.

Mankiw, G. N. (2000), The savers-spenders theory of fiscal policy. American Economic Review, 90 (papers and proceedings), 120-125.

McKinnon, R. L. (1963), Optimum currency areas. American Economic Review, 53, 473-492.

Mundell, R. A. (1960), The monetary dynamics of international adjustment under fixed and floating exchange rates. Quarterly Journal of Economics, 74, 227-257.

Mundell, R. A. (1961), A theory of optimum currency areas. American Economic Review, 51, 657-665.

Neumeyer, P. A. (1998), Currencies and the allocation of risk: The welfare effects of a monetary union. American Economic Review, 88, 246-259.

Obstfeld, M. (1986), Rational and self-fulfilling balance-of-payments crises. American 
Economic Review, 76, 72-81.

Obstfeld, M. and Rogoff, K. (1995), Exchange rate dynamics redux. Journal of Political Economy, 103, 624-660.

Obstfeld, M. and Rogoff, K. (1996), Foundations of international macroeconomics. Cambridge, Ma.: MIT Press.

Obstfeld, M. and Rogoff, K. (1998), Risk and exchange rates. Working paper, University of California/Princeton University.

Parker, J. (1999), The response of household consumption to predictable changes in social security taxes. American Economic Review, 89, 959-973.

Parsons, D. (1986), "The employment relationship", in Handbook of Labor Economics, ch. 14, O. C. Ashenfelter and R. Layard (eds.), Amsterdam: North-Holland.

Poole, W. (1970), Optimal choice of monetary policy instruments in a simple stochastic macro model. Quarterly Journal of Economics, 84, 197-216.

Rankin, N. (1998), Nominal rigidity and monetary uncertainty in a small open economy. Journal of Economic Dynamics and Control, 22, 679-702.

Seidman, L. (2001), Reviewing fiscal policy. Challenge, 44 no. 3, 17-42.

Shapiro, M. D. and Slemrod, J. (1995), Consumer response to the timing of income: Evidence from a change in tax withholding. American Economic Review, 85, 274-283.

Souleles, N. S. (1999), The response of household consumption to income tax refunds. American Economic Review, 89, 947-958.

Sutherland, A. (1995), Monetary and real shocks and the optimal target zone. European Economic Review, 39, 161-172.

Varian, H. R. (1980), Redistributive taxation as social insurance. Journal of Public Economics, $14,49-68$.

Weber, W. (1981), Output variability under monetary policy and exchange-rate rules. Journal of Political Economy, 89. 733-775. 


\title{
CESifo Working Paper Series
}

\author{
(for full list see www.cesifo.de)
}

1297 David S. Evans and Michael Salinger, An Empirical Analysis of Bundling and Tying: Over-the-Counter Pain Relief and Cold Medicines, October 2004

1298 Gershon Ben-Shakhar, Gary Bornstein, Astrid Hopfensitz and Frans van Winden, Reciprocity and Emotions: Arousal, Self-Reports, and Expectations, October 2004

1299 B. Zorina Khan and Kenneth L. Sokoloff, Institutions and Technological Innovation During Early Economic Growth: Evidence from the Great Inventors of the United States, 1790 - 1930, October 2004

1300 Piero Gottardi and Roberto Serrano, Market Power and Information Revelation in Dynamic Trading, October 2004

1301 Alan V. Deardorff, Who Makes the Rules of Globalization?, October 2004

1302 Sheilagh Ogilvie, The Use and Abuse of Trust: Social Capital and its Deployment by Early Modern Guilds, October 2004

1303 Mario Jametti and Thomas von Ungern-Sternberg, Disaster Insurance or a Disastrous Insurance - Natural Disaster Insurance in France, October 2004

1304 Pieter A. Gautier and José Luis Moraga-González, Strategic Wage Setting and Coordination Frictions with Multiple Applications, October 2004

1305 Julia Darby, Anton Muscatelli and Graeme Roy, Fiscal Federalism, Fiscal Consolidations and Cuts in Central Government Grants: Evidence from an Event Study, October 2004

1306 Michael Waldman, Antitrust Perspectives for Durable-Goods Markets, October 2004

1307 Josef Honerkamp, Stefan Moog and Bernd Raffelhüschen, Earlier or Later: A General Equilibrium Analysis of Bringing Forward an Already Announced Tax Reform, October 2004

1308 M. Hashem Pesaran, A Pair-Wise Approach to Testing for Output and Growth Convergence, October 2004

1309 John Bishop and Ferran Mane, Educational Reform and Disadvantaged Students: Are They Better Off or Worse Off?, October 2004

1310 Alfredo Schclarek, Consumption and Keynesian Fiscal Policy, October 2004

1311 Wolfram F. Richter, Efficiency Effects of Tax Deductions for Work-Related Expenses, October 2004 
1312 Franco Mariuzzo, Patrick Paul Walsh and Ciara Whelan, EU Merger Control in Differentiated Product Industries, October 2004

1313 Kurt Schmidheiny, Income Segregation and Local Progressive Taxation: Empirical Evidence from Switzerland, October 2004

1314 David S. Evans, Andrei Hagiu and Richard Schmalensee, A Survey of the Economic Role of Software Platforms in Computer-Based Industries, October 2004

1315 Frank Riedel and Elmar Wolfstetter, Immediate Demand Reduction in Simultaneous Ascending Bid Auctions, October 2004

1316 Patricia Crifo and Jean-Louis Rullière, Incentives and Anonymity Principle: Crowding Out Toward Users, October 2004

1317 Attila Ambrus and Rossella Argenziano, Network Markets and Consumers Coordination, October 2004

1318 Margarita Katsimi and Thomas Moutos, Monopoly, Inequality and Redistribution Via the Public Provision of Private Goods, October 2004

1319 Jens Josephson and Karl Wärneryd, Long-Run Selection and the Work Ethic, October 2004

1320 Jan K. Brueckner and Oleg Smirnov, Workings of the Melting Pot: Social Networks and the Evolution of Population Attributes, October 2004

1321 Thomas Fuchs and Ludger Wößmann, Computers and Student Learning: Bivariate and Multivariate Evidence on the Availability and Use of Computers at Home and at School, November 2004

1322 Alberto Bisin, Piero Gottardi and Adriano A. Rampini, Managerial Hedging and Portfolio Monitoring, November 2004

1323 Cecilia García-Peñalosa and Jean-François Wen, Redistribution and Occupational Choice in a Schumpeterian Growth Model, November 2004

1324 William Martin and Robert Rowthorn, Will Stability Last?, November 2004

1325 Jianpei Li and Elmar Wolfstetter, Partnership Dissolution, Complementarity, and Investment Incentives, November 2004

1326 Hans Fehr, Sabine Jokisch and Laurence J. Kotlikoff, Fertility, Mortality, and the Developed World's Demographic Transition, November 2004

1327 Adam Elbourne and Jakob de Haan, Asymmetric Monetary Transmission in EMU: The Robustness of VAR Conclusions and Cecchetti's Legal Family Theory, November 2004

1328 Karel-Jan Alsem, Steven Brakman, Lex Hoogduin and Gerard Kuper, The Impact of Newspapers on Consumer Confidence: Does Spin Bias Exist?, November 2004 
1329 Chiona Balfoussia and Mike Wickens, Macroeconomic Sources of Risk in the Term Structure, November 2004

1330 Ludger Wößmann, The Effect Heterogeneity of Central Exams: Evidence from TIMSS, TIMSS-Repeat and PISA, November 2004

1331 M. Hashem Pesaran, Estimation and Inference in Large Heterogeneous Panels with a Multifactor Error Structure, November 2004

1332 Maarten C. W. Janssen, José Luis Moraga-González and Matthijs R. Wildenbeest, A Note on Costly Sequential Search and Oligopoly Pricing, November 2004

1333 Martin Peitz and Patrick Waelbroeck, An Economist's Guide to Digital Music, November 2004

1334 Biswa N. Bhattacharyay and Prabir De, Promotion of Trade, Investment and Infrastructure Development between China and India: The Case of Southwest China and East and Northeast India, November 2004

1335 Lutz Hendricks, Why Does Educational Attainment Differ Across U.S. States?, November 2004

1336 Jay Pil Choi, Antitrust Analysis of Tying Arrangements, November 2004

1337 Rafael Lalive, Jan C. van Ours and Josef Zweimueller, How Changes in Financial Incentives Affect the Duration of Unemployment, November 2004

1338 Robert Woods, Fiscal Stabilisation and EMU, November 2004

1339 Rainald Borck and Matthias Wrede, Political Economy of Commuting Subsidies, November 2004

1340 Marcel Gérard, Combining Dutch Presumptive Capital Income Tax and US Qualified Intermediaries to Set Forth a New System of International Savings Taxation, November 2004

1341 Bruno S. Frey, Simon Luechinger and Alois Stutzer, Calculating Tragedy: Assessing the Costs of Terrorism, November 2004

1342 Johannes Becker and Clemens Fuest, A Backward Looking Measure of the Effective Marginal Tax Burden on Investment, November 2004

1343 Heikki Kauppi, Erkki Koskela and Rune Stenbacka, Equilibrium Unemployment and Capital Intensity Under Product and Labor Market Imperfections, November 2004

1344 Helge Berger and Till Müller, How Should Large and Small Countries Be Represented in a Currency Union?, November 2004

1345 Bruno Jullien, Two-Sided Markets and Electronic Intermediaries, November 2004 
1346 Wolfgang Eggert and Martin Kolmar, Contests with Size Effects, December 2004

1347 Stefan Napel and Mika Widgrén, The Inter-Institutional Distribution of Power in EU Codecision, December 2004

1348 Yin-Wong Cheung and Ulf G. Erlandsson, Exchange Rates and Markov Switching Dynamics, December 2004

1349 Hartmut Egger and Peter Egger, Outsourcing and Trade in a Spatial World, December 2004

1350 Paul Belleflamme and Pierre M. Picard, Piracy and Competition, December 2004

1351 Jon Strand, Public-Good Valuation and Intrafamily Allocation, December 2004

1352 Michael Berlemann, Marcus Dittrich and Gunther Markwardt, The Value of NonBinding Announcements in Public Goods Experiments: Some Theory and Experimental Evidence, December 2004

1353 Camille Cornand and Frank Heinemann, Optimal Degree of Public Information Dissemination, December 2004

1354 Matteo Governatori and Sylvester Eijffinger, Fiscal and Monetary Interaction: The Role of Asymmetries of the Stability and Growth Pact in EMU, December 2004

1355 Fred Ramb and Alfons J. Weichenrieder, Taxes and the Financial Structure of German Inward FDI, December 2004

1356 José Luis Moraga-González and Jean-Marie Viaene, Dumping in Developing and Transition Economies, December 2004

1357 Peter Friedrich, Anita Kaltschütz and Chang Woon Nam, Significance and Determination of Fees for Municipal Finance, December 2004

1358 M. Hashem Pesaran and Paolo Zaffaroni, Model Averaging and Value-at-Risk Based Evaluation of Large Multi Asset Volatility Models for Risk Management, December 2004

1359 Fwu-Ranq Chang, Optimal Growth and Impatience: A Phase Diagram Analysis, December 2004

1360 Elise S. Brezis and François Crouzet, The Role of Higher Education Institutions: Recruitment of Elites and Economic Growth, December 2004

1361 B. Gabriela Mundaca and Jon Strand, A Risk Allocation Approach to Optimal Exchange Rate Policy, December 2004 